http://dx.doi.org/10.4314/ejotmas.v7i1-2.20

\title{
COSTUMES AS DEPICTION OF CULTURAL IDENTITY IN PEDRO AGBONIFO-OBASEKI'S IDIA
}

\author{
*Owens Patricia EROMOSELE
}

\begin{abstract}
In Nigeria, costumes present interesting vistas for exploring cultural identity. They have social implications and at times are politically implicated. This may be attributed to Nigeria's multi-cultural atmosphere that makes costumes a reflection of the cultural identity of the people. Nigerian performances in festivals and play productions provide a platform to study and appreciate this phenomenon. Using the participant observation and literary methods, this article interrogates how costumes can depict the cultural identity of a people. It appropriates the dynamics of costumes as depiction of indigenous identity, using a play production of Pedro Agbonifo-Obaseki's Idia as directed by Israel Wekpe under the aegis of the Edo State Chapter of National Association of Nigerian Theatre Arts Practitioners (NANTAP) at the University of Benin in 2013. The study reveals that costume promotes the cultural worldview of the people it represents. The conclusion reached is that costumes in Nigeria must depart from such outside influences that undermine their ability to communicate indigenous identity.
\end{abstract}

Keywords: Costume, Cultural identity, Idia, Play production, Nonverbal communication

\section{Introduction}

Costumes are some of the important elements in the promotion and sustenance of cultural heritage. This can be observed through various media such as play productions, cultural events, festival celebrations, etc. Costumes reflect the people's culture and create a unique identity about a group of people and the society they represent. Nigeria is known for its traditional art cultures of the Benin, Igbo, Nok, Ife, etc. This phenomenon has over the years filled the gap of non-verbal communication. This is so because persons can easily be identified

*Owens Patricia EROMOSELE is of the Department of Theatre Arts, University of Benin, Benin City, Nigeria

Email: owens4pat@gmail.com 
by their mode of dressing without any form of verbal communication. This has also reflected in play productions.

The use of costume by a character in a play creates an identity for that character. In play productions, costume speaks to the audience about the personality of the character before it. In an attempt to enable costume speak; costume resources are manipulated by the costume designer/costumier in order to effectively pass out the required information as prescribed in the play. Costume in play performances assists the director to interpret the adopted directorial concept effectively. Costumes are designed to assist both the actors and audience in understanding characters' personality, mood, status and thereby assisting to promote effective non-verbal communication system in play performances. Hence, Emery submits that "a theatrical costume becomes a visual extension of the actor and the character portrayed" (4).

Stage costumes have the ability to create awareness about what it is communicating. It is this understanding that made Ommanney and Schanker to assert that "a stage costume should create awareness about character's personality, revealing social status, tastes, and idiosyncrasies. It should aid the understanding of the actor's relationship to the other characters and to the play itself" (348). The construction of costume for play productions can be achieved through detailed study of the culture of the play as presented by the playwright as well as research on the character as indicated in the script. This is why Ommanney and Schanker say that "the first step in costume design, as in all phases of theatre production, is to study the play carefully" (350). This aspect of design adds to the visible appearance of the performer. Additionally, Lyndersay opines that:

Costumes for any kind of presentation contribute to the outward and visible appearance of the performer - actor, dancer or musician. Before a modern-day costume designer begins to study the needs, the choices, and the options available to assist his creativity, an understanding of the original motives and desires for embellishing the human form must be investigated and understood.(2)

This visible and outward appearance that Lyndersay pointed out responds to the culture of the play as presented in the play and also situates the performance to a particular culture or society and within a particular period in history. 


\section{Synopsis of the Play, Idia}

Idia is a historical play written by Pedro Agbonifo-Obaseki. It has a Benin setting that presents the historical event of Queen Idia the mother of Esigie, the Oba of Benin Kingdom, who ruled from 1504-1550. After the death of Oba Ozolua, his two sons, Arhuaran ruled over Udo, while Esigie the son of Idia was made to rule as the Oba of Benin. Queen Idia contributed to the rise and reign of her son, Esigie thereby leading the Benin warriors to defeat Igala warriors during the reign of Oba Esigie. After the defeat of the Igala warriors by the Benin warriors, Queen Idia became the first mother of the Oba to be given the title of lyoba (Queen Mother) and held the title of Egua-lyoba (Palace of the Queen Mother).

\section{Costume as a Reflection of Cultural Identity in Plays}

The influence of the Whiteman has almost wiped away the significance of indigenous costume in African cultural settings. English wears have become a new trend of fashion among African youths and even the elderly. Exhibiting African indigenous attires has become a challenge in contemporary time. Thus, the average man or woman's everyday outing is more of English wears than the traditional wears in many parts of Africa, including the southern region of Nigeria. In spite of this challenge, play productions have become a platform to project African indigenous identity. Through different play performances such as Lagbodo by Wale Ogunyemi, Obaseki by Pedro Agbonifo-Obaseki, The Last Emperor by Ossai Earliece, among others, the culture of the people is projected and thereby helps to sustain it. Play performances have over the years been an active medium through which younger generations can learn and know more about their culture through the content of the story and the use of indigenous costumes. This is ostensibly because costume is an agent of societal transformation.

According to Adedeji and Ekwuazi in Ekere and Amala, "environment serves as a strong base for creative activities." Emoruwa cited in Ekere and Amala corroboratively asserts that "the contentual and contextual forms, style, patterns, conventions and design are hinged on the culture, beliefs and worldview of the people who create and practice it" (26). The foregoing speaks to the fact that costume in theatrical productions depicts the cultural worldview of the society indicated in the play. The culture of the people is visually amplified through the construction of appropriate costume. Culture which is the belief system of a group of people, their way of life, occupation, language and mode of dressing is projected via theatrical productions.

Costume designs are peculiar artifacts of identifiable ethnic groups. Each ethnic group has different fabrics and colours peculiar 
to it and the name of the fabrics differs even though there may be similarities in the colours in different groups. The meaning of traditional costumes and their colours is attributed in a way to the belief of that particular culture. For example, the Benin are known for different colours such as purple, gold, white, red, blue, etc. even though the red and white is dominant in the royal court. The white symbolizes purity while the red symbolizes courage. The Benin people also use coral beads which are the symbols of great wealth brought by Olokun, the god of wealth. In the words of Umukoro cited in Utoh-Ezeajugh, costume is cultural symbolism (134). Umukoro further claims that:

Cultural symbolism is the hallmark of the Nigerian traditional dress. It is consciously or unconsciously evolved to bear emblems unique to its owners. Such emblems may be derived from common features in the environment, it may also, by persistent contact of an Ethnic group with some other, be a feature borrowed appropriate and seemingly endorsed by a widespread acceptance and use of its ethnic symbol. (134)

To Kwakye-Opong and Adinke, culture is "social and objective fact which moulds us into either a Ghanaian or a Nigerian because the society of our origin gives it to us" (2). The costumes in Idia goes beyond serving as a cover to the characters, it communicate the people's identity which cut across different social groups in Benin, both the royal status and the non-royal, belief system, attitudes, norms, values and feelings.

\section{Costume Design in Perdo Agbonifo-Obaseki's Idia Play Production}

In costuming the play, which was produced by the Edo State Chapter of National Association of Nigerian Theatre Arts Practitioners (NANTAP) at the University of Benin in December 2013, the costume designer researched into the dress culture of the Benin people having in mind the historical account of how Benin dress was like as at that time in history. However, in theatrical productions, directors can approach a play with his/her concept. The director determines how the play should flow. In staging this play, the director (Israel Wekpe), however, adopted a contemporary setting. The costume designer (Owens Eromosele) built her ideas to fit into the director's concept. A contemporary approach was given to the costume designed for the play. Each character was costumed in contemporary designs to suit the demand of the play production. The characters were costumed to reflect their personalities and their statuses in the role they are playing. Costumes worn by the characters in the play assist in creating a visual aesthetic that will communicate well about the Benin culture. The application of 
costume and the justification of colour usage create a more appealing view of the play. It helps for character and cultural interpretation. This is made possible by the costume designer who undertakes a background study of the culture of the people. The costume was also designed to reflect the mood of the characters.

\section{Idia: Character Costume Analysis}

Idia, as the lead character, was costumed in the traditional Benin way of dressing. She appeared in three different kinds of costumes. The costumes selection was made depending on the given circumstances. There is the casual costume, court appearing costume and warrior costume. The casual costume was used in the first scene she appeared. The costume consist of a red colour ugbegbe (velvet) wrapper and coral beads (ivie) as accessories. The wrapper was tied across the chest. She also made use of coral beads for both hands and legs with okuku (headgear). This colour is a traditional colour for the Benin people. For the court appearing, blue Ugbegbe (velvet) wrapper was tied by the queen in every court meeting and during the coronation scene. This colour was chosen to distinguish her from other commoners that may appear in the scene and also for aesthetic purpose. She also made use of coral beads for both hands and legs with okuku (a high headgear decorated with beads).

The warrior costume was used towards the end of the play; it was used in the scene that shows Idia warriors preparing for battle and also used during and after the war with the Idah warriors. The costume was designed with red cotton material in skirt and blouse style. The costume was a short sleeve shirt and a skirt above the knee with charms attached to it for the purpose of emphasis and a headgear which is a symbol of authority and leadership. 


\section{Plate1}

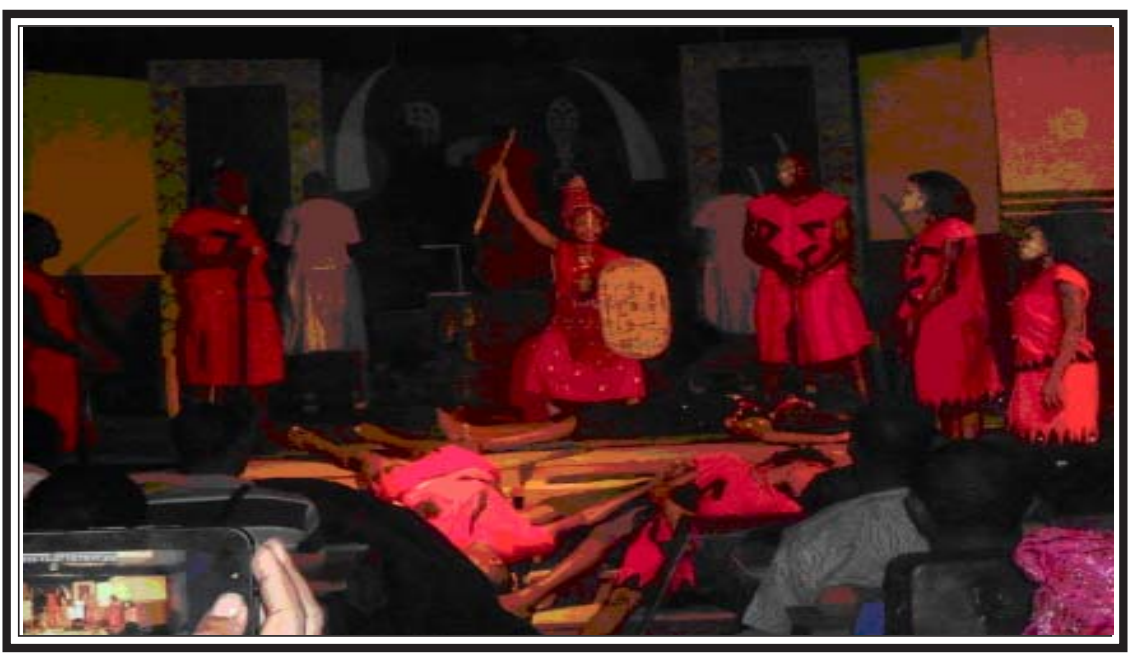

The warriors on their warrior outfits after defeating the Igala warriors. At the middle is Idia who lead the troop

\section{Plate 2}

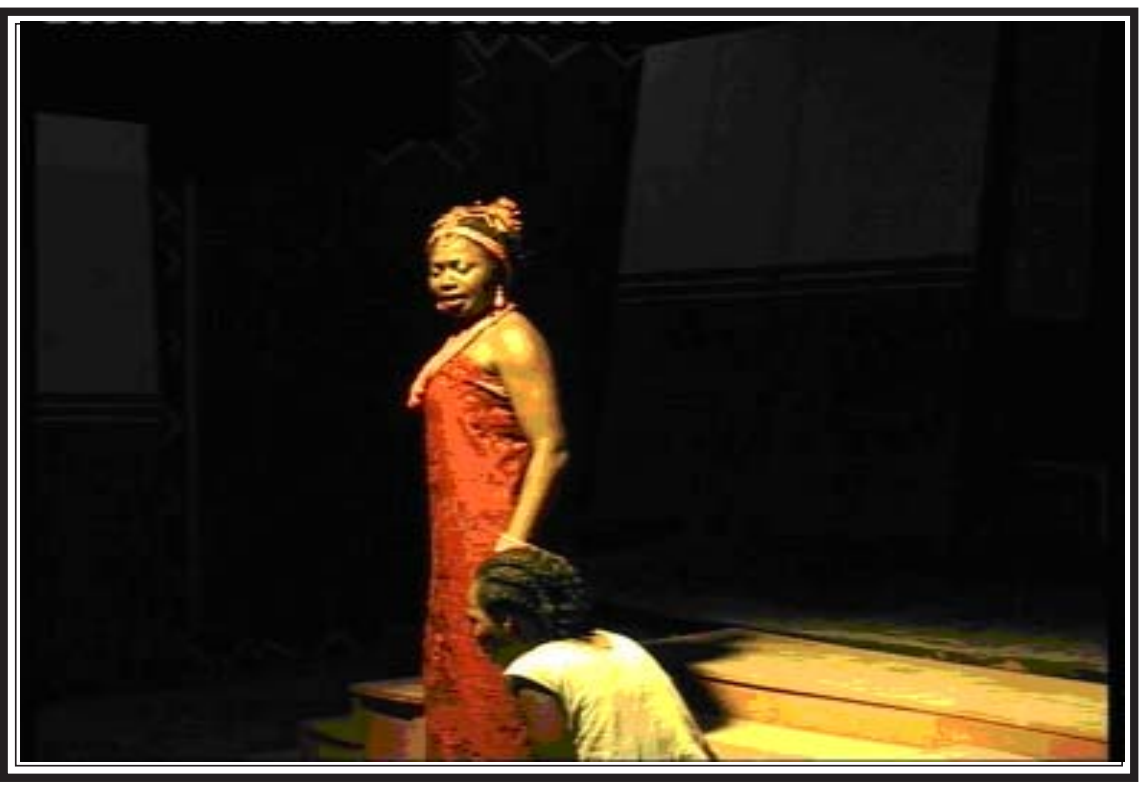

Queen Mother on red ugbegbe and her slave on milk shirt and skirt 


\section{Plate 3}

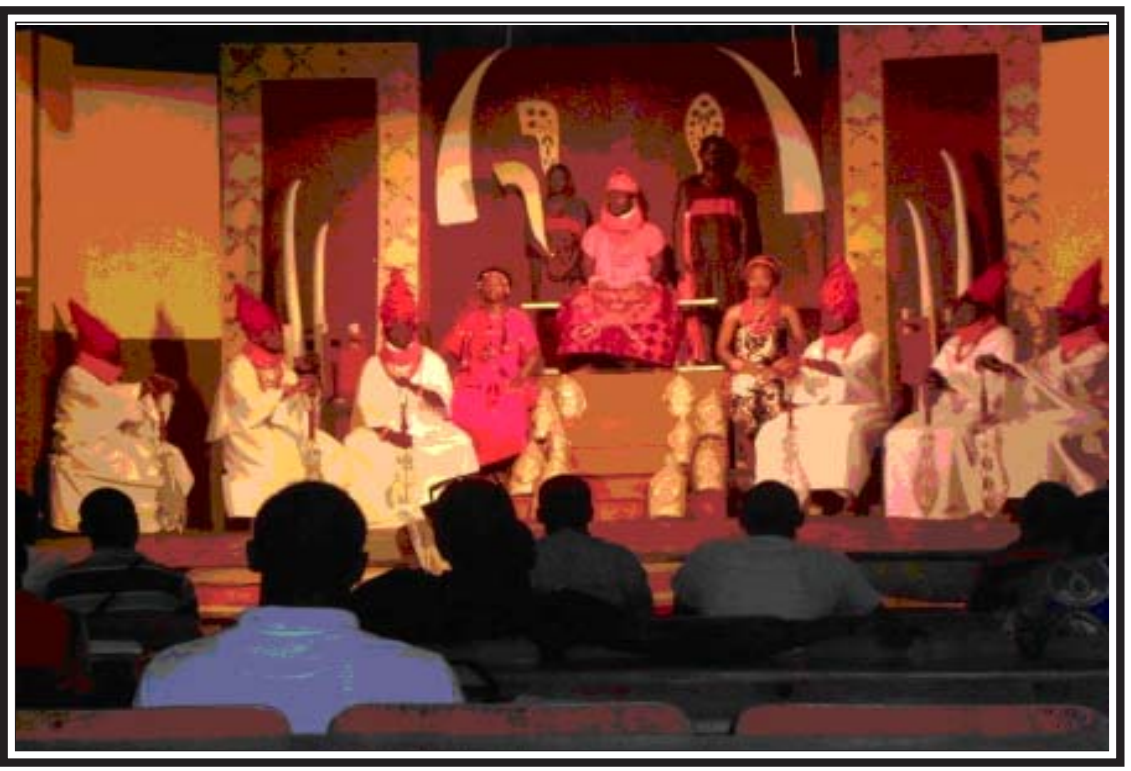

Idia on a blue ugbegbe wrapper tied on her chest with chiefs in white on white with cape and headgear, while the Oba on red skirt with beaded shirt. Behind the Oba are two slaves on brown shirt and skirt with red design

\section{Chiefs: Character Costume Analysis}

The chiefs appeared in two colours in the play. They appeared on a mixture of red and red and a complete white and white with a cape and a headgear. In the scene where ritual was performed in honour of the deceased king, some of the chiefs were costumed on complete red and red, some on white and white while the Isekhure (chief priest) was on a red blouse and a white skirt. These costumes were also used in any other court appearing scenes. White without cape was worn as a normal everyday outing cloth for the chiefs. But for the complete white and white with cape and headgear, it was worn on a special occasion, especially for ceremonial events such as the crowing of the new Oba which was a special event at the opening of the play. The costume was designed not originally as it is in the real Benin culture, but it was designed to nearly meet the demand to which it was created for. 


\section{Plate 4}

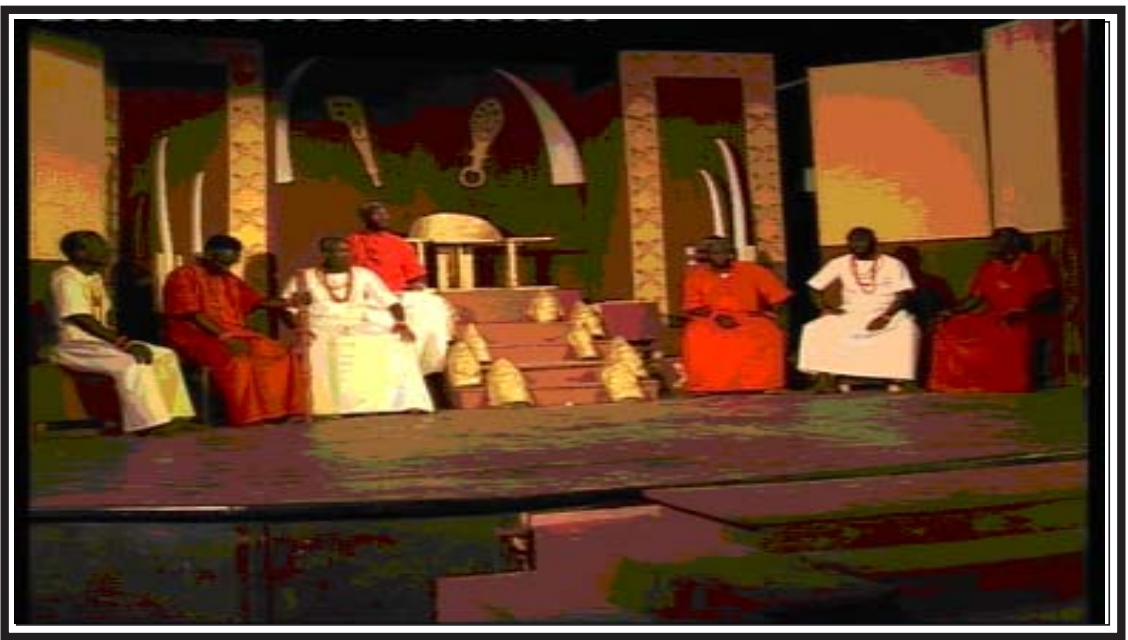

Chiefs on their casual costume for everyday outing

\section{Oba: Character Costume Analysis}

The Oba appeared in both casual and ceremonial costumes. The ceremonial costume comprises a beaded shirt and a buluku (skirt) with Ada and Eben inscription on it. This costume was used during the coronation scene. He also uses two different crowns for different occasions. The costume designed was made to give a royal symbol to the Oba and to project him as the number one citizen of the people. The Oba costume is not made the same with the other members of the community. 
Plate 5

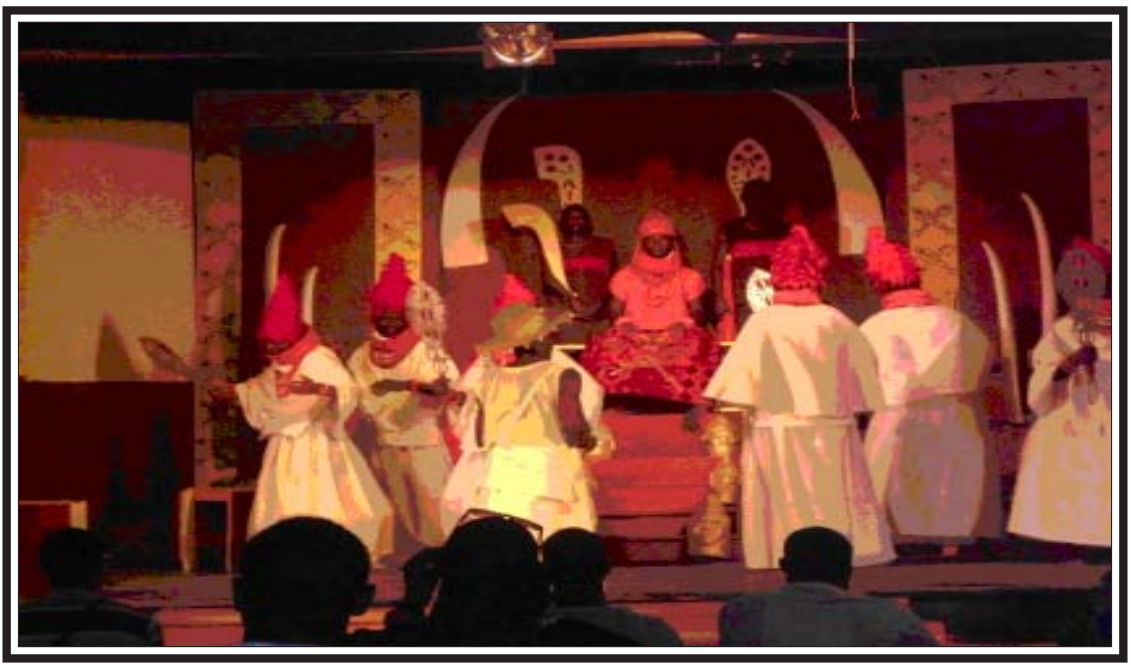

The Oba and his chiefs on ceremonial attires

Plate 6

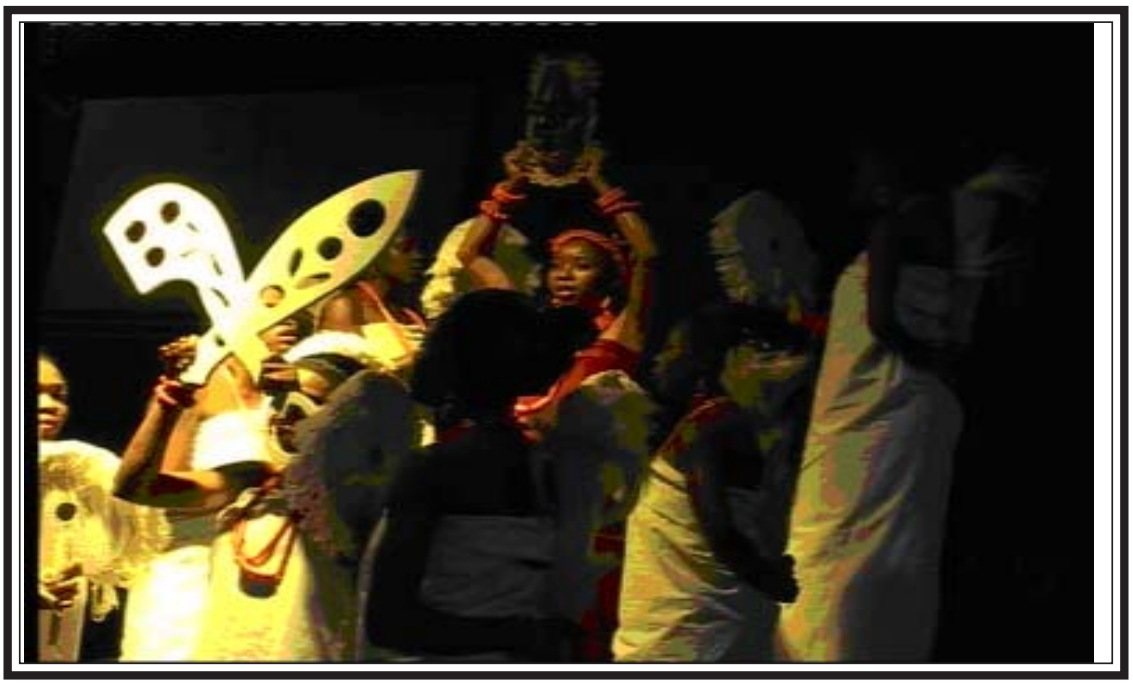

The mask carrier on red ugbegbe (velvet) at the middle with the isekhien women on white wrapper tied on their chests 


\section{Plate 7}

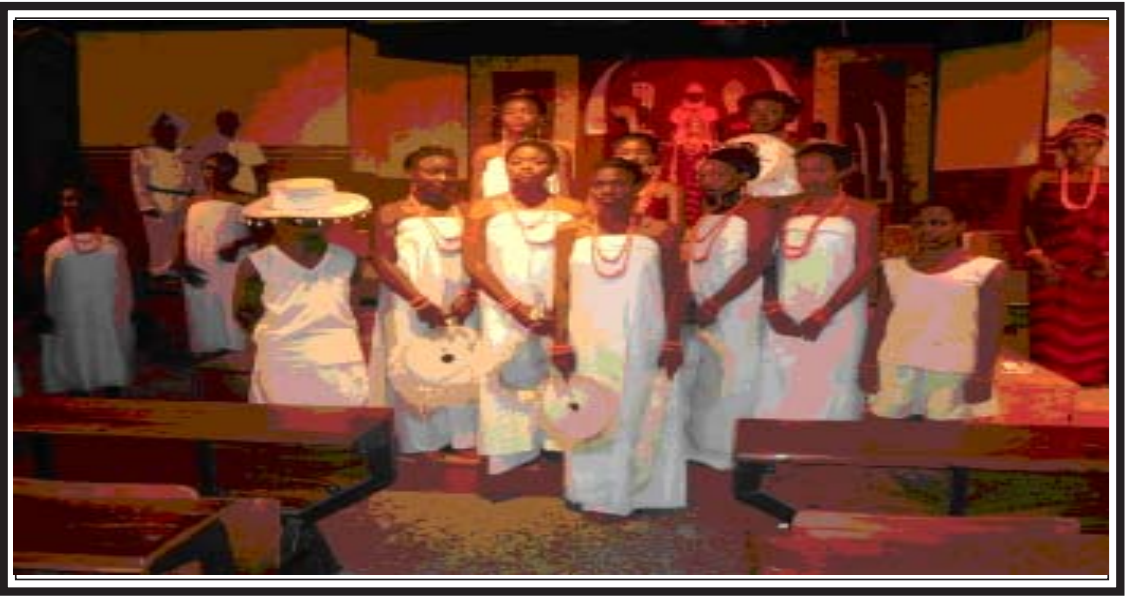

On the left is uke, the isekhien women and Queen Idia's maid

The dominant colours used for the performance is white and red designed with a contemporary approach. The colours are a reflection on the Benin culture.

\section{Findings}

Costumes use in the play production of Idia presents the Benin indigenous worldview and helps to identify the social hierarchy of Benin people. From the costume, one can identify the various roles each character is playing. Specifically, the study revealed that for costume to be able to communicate effectively in any production there must be detailed research on the culture presented by the costume designer. The ability of costume to create awareness about the nature of the play depends on the costume designer's ability to undergo a detailed research about the play, character, status, personality, etc., in relation to the culture of the people as depicted in the play by the playwright. The ability for costume to provide valid information about a culture is determined by the appropriate designing of costume for the characters. It also supports the plot to give valid information about a people's culture.

\section{Conclusion}

This paper has examined how costume for play productions can serve as socio-cultural instruments of the people using Idia by Pedro Agbonifo-Obaseki, a historical play, to portray the Benin culture. The 
study was successfully carried out with appropriate research into the culture of the play, roles and social statuses of the characters. In play productions, costume has become one of those symbols through which people's culture can be identified and appreciated. It is a viable means in sustaining culture and it allows the viewing audience seated at the performance space to appreciate the culture. Creating an appealing costume that depicts the people's culture and value for a play production requires the creative ability of a costume designer and skills in artistic manipulation. It has been observed that appropriateness in costume design can yield an appealing and acceptable production by the people. The study, therefore, concludes that Idia is culturally rooted in the traditions of the Benin people. This is so because costume is a depiction of the culture of the people as presented in the play performance that was X-rayed.

\section{Works Cited}

Agbonifo-Obaseki, Pedro. Idia. Dir. Israel M. Wekpe, Performance held at the Theatre Hall, Ekehuan Campus, University of Benin, Benin City, Edo State, Nigeria, from December 25-29, 2013.

Emery, Joy. Stage Costuming Techniques. Englewood Cliffs: PrenticeHall, 1981. Print.

Ekere, Gloria D. and Amala A. Abdulmalik. "Cultural Influences and Considerations on Costume and Makeup Design in Mbopo Celebration of the Efik/lbibio."Ed. Duro Oni Technical Theatre and the Performing Arts in Nigeria. Lagos: CBAAC, 2011. 24-28. Print.

Harry, H. S. and Katherine, A. O. The Stage and School. 5th edition. New York: McGraw-Hill Book Company, 1982. Print.

Kwakye-Opong and Adeniku, Grace U. "Costume as a Medium of Cultural Expression in Stage Performance." Arts and Design Studies 8 (2013): Print.

Lyndersay, Dani. Nigerian Dress :The Body Honoured. Ibadan: CBAAC, 2011. Print.

Utoh-Ezeajugh,Tracie. "Promoting Minority Culture through Costume and Makeup."Ed. Austin Asagba. Theatre and Minority Rights: Perspectives on the Niger Delta. Ibadan: Kraft, 2009. 129141. Print. 